University of Nebraska - Lincoln

DigitalCommons@University of Nebraska - Lincoln

Agronomy \& Horticulture -- Faculty Publications

Agronomy and Horticulture Department

March 1999

\title{
Switchgrass Seedling Development as Affected by Seed Size
}

Alexander J. Smart

University of Nebraska-Lincoln

Lowell E. Moser

University of Nebraska-Lincoln, Imoser1@unl.edu

Follow this and additional works at: https://digitalcommons.unl.edu/agronomyfacpub

Part of the Plant Sciences Commons

Smart, Alexander J. and Moser, Lowell E., "Switchgrass Seedling Development as Affected by Seed Size" (1999). Agronomy \& Horticulture -- Faculty Publications. 68.

https://digitalcommons.unl.edu/agronomyfacpub/68

This Article is brought to you for free and open access by the Agronomy and Horticulture Department at DigitalCommons@University of Nebraska - Lincoln. It has been accepted for inclusion in Agronomy \& Horticulture -Faculty Publications by an authorized administrator of DigitalCommons@University of Nebraska - Lincoln. 


\title{
FORAGES \& TURFGRASS
}

\section{Switchgrass Seedling Development as Affected by Seed Size}

\author{
Alexander J. Smart* and Lowell E. Moser
}

\begin{abstract}
Seed size has been associated with early seedling vigor (i.e., germination rate, emergence rate, and growth) in grasses. This study was conducted to compare seedling development over a $60-\mathrm{d}$ period in

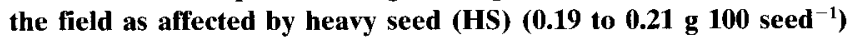
and light seed (LS) (0.13 to $\left.0.16 \mathrm{~g} 100 \mathrm{seed}^{-1}\right)$ of 'Blackwell' and 'Trailblazer' switchgrass (Panicum virgatum L.). The experiment was conducted in 1995 and 1996 at Lincoln, NE, on a Kennebec silt loam (fine-silty, mixed, superactive, mesic Cumulic Hapludolls). The experimental design was a randomized complete block with four replicates. Seed was separated into two sizes using a South Dakota seed blower. Seed was planted into rows at a rate of 100 pure live seed per meter of row. Plants were excavated and evaluated for shoot weight, leaf area, and root weight. Shoot and root systems were morphologically staged four times during the summer. Seed size differences in switchgrass appeared to produce only slight differences in morphological development of shoot and root systems, leaf area, shoot weight, and adventitious root weight from seedling emergence to 6 wk of growth. Adventitious roots formed more quickly on seedlings from heavier than lighter seed, but the advantage to seedling establishment was minimal even when soil moisture appeared to be lacking. By 8 to 10 wk after emergence, growth and development of LS seedlings were similar to HS seedlings. Once seedlings formed two or more adventitious roots, seed size no longer affected establishment and growth. Seed size in switchgrass appears to have a minimal long-term effect on growth and development of seedlings.
\end{abstract}

$\mathrm{T}$ HE TWO PHASES of perennial grass establishment are seed germination and emergence, and the development of the adventitious root system (Newman and Moser, 1988). Lack of successful establishment of perennial forage grasses such as switchgrass has been attributed to inadequate moisture, weed competition, and low seedling vigor. Breeding programs have been conducted to improve grass establishment by improving seedling vigor through selecting for heavier seed. Kneebone (1972) reported that within a grass species, heavy seed has a higher germination rate (Kneebone and Cremer, 1955; Rogler, 1954; Tossell, 1960) and seedlings have greater emergence (Kneebone and Cremer, 1955; Rogler, 1954; Tossell, 1960) and more rapid growth after emergence (Kneebone and Cremer, 1955; Tossell, 1960; Trupp and Carlson, 1967) than with light seed. Recent work on switchgrass also has shown that heavy seed has a higher germination rate and seedlings have greater

A.J. Smart and L.E. Moser, Univ. of Nebraska-Lincoln, Agronomy Dep., 279 Plant Sci. Lincoln, NE 68583. Nebraska Agric. Exp. Stn. Journal series no. 12187. Recieved 2 Apr. 1998. *Corresponding author (asmart@unl.edu).

Published in Agron. J. 91:335-338 (1999). emergence and faster growth rates than light seed (Aiken and Springer, 1995; Green and Bransby, 1995).

Most investigations evaluating seedling growth in perennial grasses have been conducted in growth chambers or greenhouses, with seedling growth characteristics measured over a short period of time during the seedling emergence phase. Field studies with annual grain crops such as corn (Zea mays L.) and wheat (Triticum aestivum L.) have shown no relationship between seed size and grain yield (Graven and Carter, 1990; Hunter and Kannenberg, 1972; Douglas et al., 1994). Little research has been conducted relating seed size to the adventitious root development phase of grass seedling establishment. With cool-season grasses, heavy seed planted in Washington rangeland showed greater emergence in $3 \mathrm{wk}$ than did lighter seed, but stand establishment, percentage survival, and second-year forage production per plant were not affected (Kittock and Patterson, 1962). In addition, Kittock and Patterson concluded that the higher seedling vigor from heavy seed was only short-lived and that moisture stress tended to equalize the growth from seed of different sizes. Formation of adventitous roots is critical to seedling survival (Hyder et al., 1971; Newman and Moser, 1988; Ries and Svejcar, 1991) and depends on adequate soil surface moisture (Newman and Moser, 1988; Wilson and Briske, 1979). Our objective was to determine the effect of heavy seed (HS) and light seed (LS) on seedling development during the establishment phase (transition from primary root development to adventitious root formation) of switchgrass grown in the field.

\section{MATERIALS AND METHODS}

This study was conducted in 1995 at the University of Nebraska Havelock Farm in Lincoln, NE, and in 1996 at the East Campus of the University. of Nebraska-Lincoln. The soil for both sites was a Kennebec silt loam (fine-silty, mixed, superactive, mesic Cumulic Hapludolls). Rainfall and temperature were obtained within $1 \mathrm{~km}$ of each set of plots from monitoring stations of the University's Institute of Agriculture and Natural Resources. The field was moldboard plowed in the fall and the seedbed was prepared in May of both years with a spring-tooth harrow. Weeds were controlled by a single preemergence herbicide application of atrazine [6-chloro- $N$ ethyl- $N^{\prime}$-(1-methylethyl)-1,3,5-triazine-2,4-diamine] at $2.24 \mathrm{~kg}$ $\mathrm{ha}^{-1}$ after planting and hand-weeding when necessary.

The experimental design was a randomized complete block with four replicates. Treatments were arranged in factorial combinations of two seed sizes (HS and LS), two switchgrass cultivars (Blackwell and Trailblazer), and two seedlots within

Abbreviations: HS, heavy seed; LS, light seed; MSCR, mean stage count root; MSCS, mean stage count shoot. 
Table 1. Weight of 100 seeds and germination of Blackwell and Trailblazer switchgrass, averaged over two seedlots and four replications.

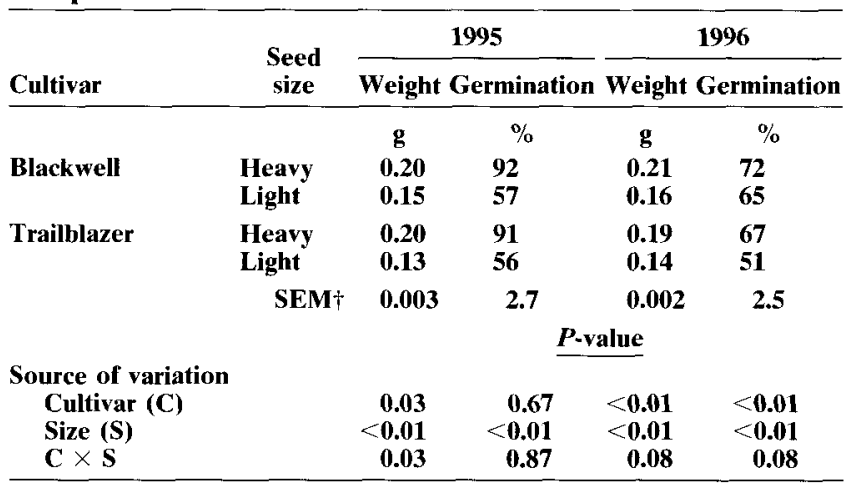

$\dagger$ SEM, standard error of the mean.

each cultivar. The experimental unit was two 12-m-long rows seeded to a single cultivar-seedlot-seed size combination. A sampling unit was a group of 20 consecutive seedlings excavated from the experimental unit. A 5-g sample of seed was separated into heavy and light seed (Table 1) using a South Dakota Seedblower (E.L. Erickson Products, Brookings, SD). This process was repeated until enough seed was collected to plant each row. A germination trial (Table 1) was conducted for $3 \mathrm{wk}$ on the seed to adjust seedlots to the same proportion of pure live seed. The germination chamber was set for alternating temperatures of $20^{\circ} \mathrm{C}$ for $16 \mathrm{~h}$ (dark) and $30^{\circ} \mathrm{C}$ for $8 \mathrm{~h}$ (light). Areas to be planted were hand-raked to smooth the surface and remove large clods. The areas were planted with a single-row, precision grass-seed cone planter (Kincaid Equipment Manufacturing, Haven, KS) to a depth of 0.6 to $1.3 \mathrm{~cm}$ at 100 pure live seed per meter of row on 31 May 1995 and 6 May 1996. Row spacing between treatments was 0.75 $\mathrm{m}$. Rows were divided into $3-\mathrm{m}$ sections and randomly assigned to four sampling dates. The first sampling date occurred when seedlings were distinguishable in a row, and sampling continued every 2 wk until 8 to $10 \mathrm{wk}$ after planting.

Twenty seedlings from each plot were excavated to a depth of $20 \mathrm{~cm}$ with a spade. Most of the soil was gently removed from the roots in the field, leaving the roots intact. Roots were washed in the lab to remove any remaining soil. Nearly all root mass was recovered with this technique. Samples were then stored in plastic bags at $5^{\circ} \mathrm{C}$ until morphological staging

Table 2. Growth stages, numerical indices, and descriptions for staging grass seedling shoots and roots. $\dagger$

\begin{tabular}{|c|c|c|}
\hline Stage & Index & Description \\
\hline \multicolumn{3}{|l|}{ Shoot } \\
\hline S1 & 1.0 & Coleoptile emerged from seed \\
\hline S2 & 2.0 & Emergence of leaf from coleoptile \\
\hline $\mathbf{S 3}$ & 3.0 & Appearance of collar/ligule of first leaf \\
\hline S4 & 4.0 & Appearance of collar/ligule of second or third leaf \\
\hline S5 & 5.0 & Appearance of collar/ligule of fourth to sixth leaf $\neq$ \\
\hline S6 & 6.0 & Appearance of first secondary tiller \\
\hline $\mathbf{S 7}$ & 7.0 & Appearance of second secondary tiller \\
\hline $\mathbf{s 8}$ & 8.0 & Appearance of third secondary tiller \\
\hline \multicolumn{3}{|r|}{ Tr } \\
\hline R1 & 1.0 & Radicle emergence from seed \\
\hline R2 & 2.0 & Primary root branching/seminal root formation \\
\hline $\mathbf{R 3}$ & 3.0 & Appearance of first adventitious root \\
\hline R4 & 4.0 & Appearance of two to three adventitious roots \\
\hline R5 & 5.0 & Appearance of four to six adventitious roots \\
\hline R6 & 6.0 & Appearance of seven to ten adventitious roots \\
\hline R7 & 7.0 & Appearance of ten or more adventitious roots \\
\hline R8 & 8.0 & Appearance of first true rhizome \\
\hline
\end{tabular}

$\dagger$ From Moser et al. (1993).

\$ The number of leaves or roots in these stages can be changed, providing flexibility to accommodate a wide range of developmental variation among species.

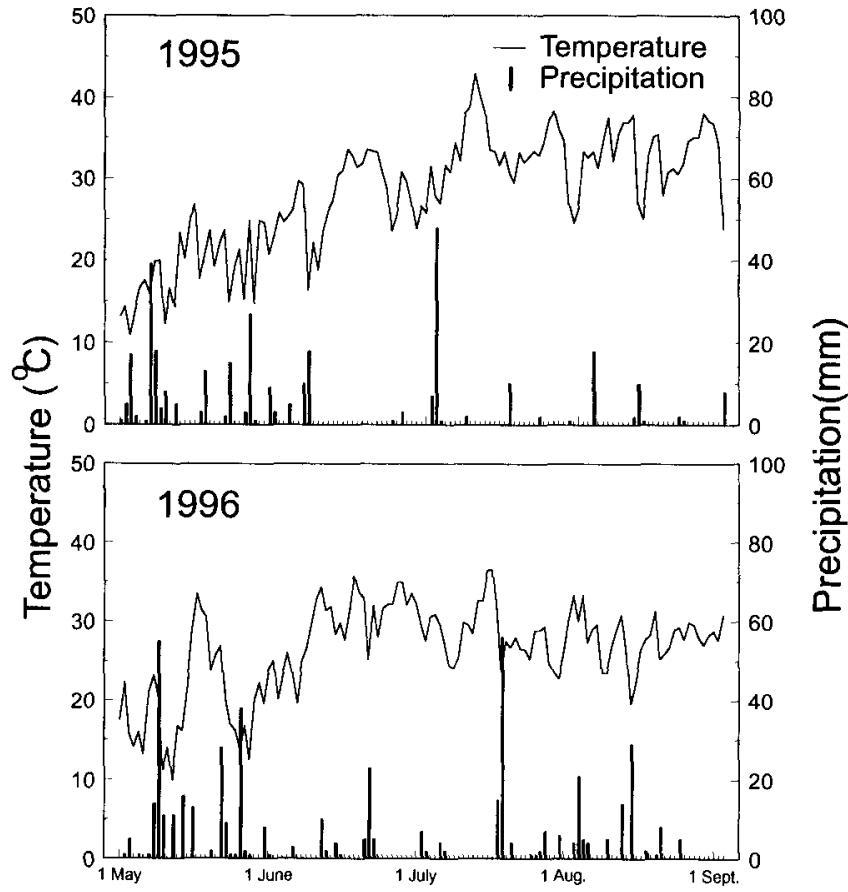

Fig. 1. Maximum daily temperature and rainfall at Univ. of NebraskaLincoln East Campus and Havelock Farm during 1995 and 1996 growing season.

was done and plant component weights were determined. Seedling morphology was quantified as to mean stage count root (MSCR) and mean stage count shoot (MSCS), using the index developed by Moser et al. (1993) (Table 2). Mean stage count equals the growth stage index value multiplied by the number of seedlings in that stage and summed over all stages from 1 to 8 and divided by the total number of seedlings. Additionally, leaf area, shoot dry weight, and adventitious root dry weight were measured to quantify seedling development. Leaf area was measured on the 20 -seedling sample by removing the leaf blades at the collar and putting the blades through a LI-3000 portable area meter (LI-COR, Lincoln, NE). Analysis of variance (SAS, 1985) was performed on all variables within a common sampling date, and means were separated using Fisher's protected least significant difference at $\alpha=0.05$ (Steel and Torrie, 1980).

\section{RESULTS AND DISCUSSION}

Germination was greater for heavy than for light seed (Table 1), which agrees with previous work (Aiken and Springer, 1995; Green and Bransby, 1995; Kneebone and Cremer, 1955; Rogler, 1954; Tossell, 1960). In 1995, rainfall was concentrated in May and early June with less precipitation occurring in the remaining summer months (Fig. 1). Rainfall was more evenly distributed in 1996. Temperature was similar for both years, except for a warm period in mid-May 1996. These weather differences, combined with the earlier planting date and different location in 1996, produced seedlings with at least 10 times more biomass in 1996 than in 1995 (Fig. 2 and 3 ).

\section{Shoot Development}

There were no significant interactions of seed size with cultivar or seedlot, nor was there a significant cultivar and seed lot effect at any sampling date for MSCS, 

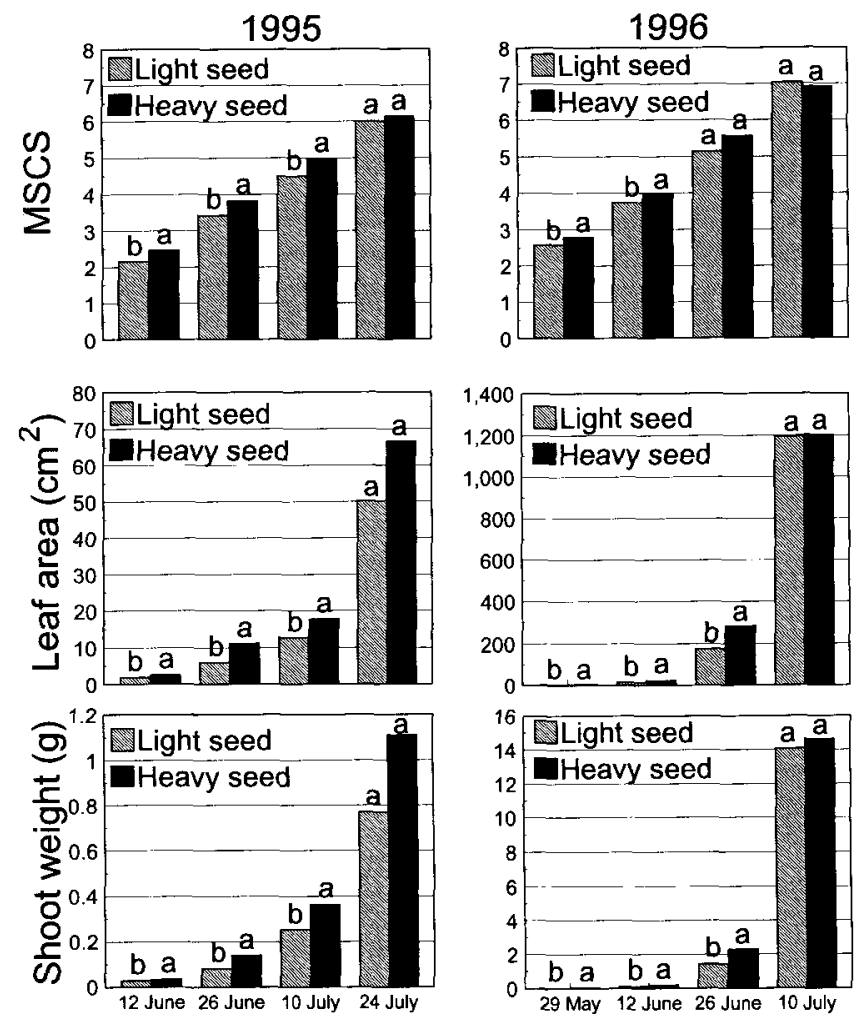

Fig. 2. Mean stage count shoot (MSCS), leaf area, and shoot dry weight of 20 switchgrass seedlings sampled throughout the growing season of light seed and heavy seed switchgrass in 1995 and 1996 at Lincoln, NE. Means with different letters within same sampling date are significantly different at $P=0.05$. Note that $y$-axis scales differ between years for leaf area and shoot weight.

leaf area, and shoot weight. There was a year $\times$ seed size interaction for MSCS, leaf area, and shoot weight at one or more of the sampling dates (Table 3). The HS seedlings had a higher MSCS than LS seedlings early in the growing season, but were similar at the end of 8 wk (Fig. 2). Leaf area was much less in 1995 than in 1996, although the trend for leaf area accumulation through the growing season was similar for both years. In both years, HS seedlings had more leaf area through the first three sampling dates but were similar to LS seedlings at the fourth sampling date (Fig. 2). Shoot weight showed the same response as did leaf area for both years and seed sizes (Fig. 2). These results indicate that there was no advantage in greater early leaf area, shoot weight, or advanced morphological development for seedling establishment. In corn, small and large seed produced similar yields and vegetative biomass at the end of the growing season (Graven and Carter, 1990; Hunter and Kannenberg, 1972). Early in the growing season, corn plant height was slightly less for small-seed vs. large-seed plants (Hunter and Kannenberg, 1972). In wheat, small and large seed sizes produced plants with similar early season growth and grain yield (Douglas et al., 1994).

\section{Root Development}

There were no significant interactions of seed size with cultivar or seedlot, nor a significant cultivar and seed lot effect for MSCR and adventitious root weight.
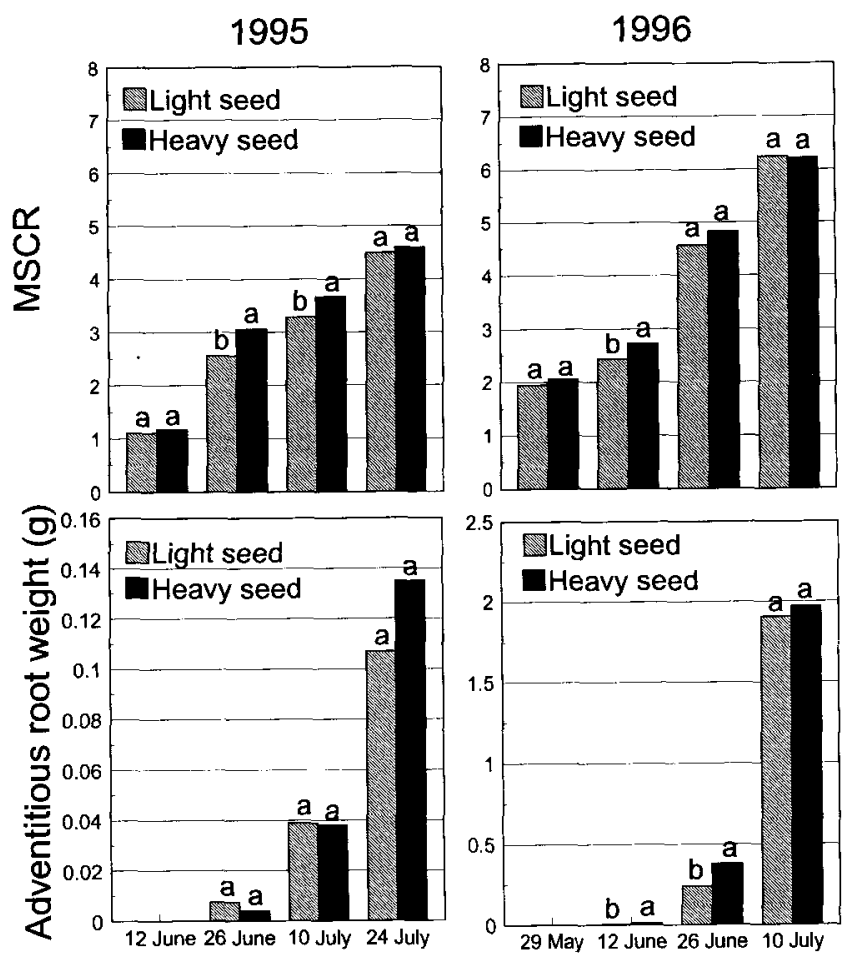

Fig. 3. Mean stage count root (MSCR) and adventitious root dry weight of 20 switchgrass seedlings sampled throughout the growing season of light seed and heavy seed switchgrass in 1995 and 1996 at Lincoln, NE. Means with different letters within same sampling date are significantly different at $P=0.05$. Note that $y$-axis scales differ between years for adventitious root weight.

There was a significant year $\times$ seed size interaction for adventitious root weight at one or more of the sampling dates, but not for MSCR (Table 3). Mean stage count root was higher for HS seedlings in the middle two dates but was the same for both seed sizes for the first and last sampling dates (Fig. 3). Root stage for HS and LS seedlings was similar at the first sampling date in both years, because the first index value for MSCR corresponds to the radicle emergence and primary root formation. Differences in MSCR between HS and LS seedlings occurred at later sampling dates because HS seedlings developed adventitious roots more quickly. Biomass production of adventitious roots was greater in 1996 than in 1995. Adventitious root weight in 1995 was similar for both seed sizes at all sampling dates (Fig. 3). Apparently, LS seedlings had fewer but longer adventitious roots than HS seedlings at the middle sampling dates.

The midsummer of 1995 was dry. Since adequate soil

Table 3. Probability of year $\times$ seed size interaction for seedling variables in switchgrass, measured at four sampling dates in the summers of 1995 and 1996.

\begin{tabular}{|c|c|c|c|c|c|}
\hline \multirow[b]{2}{*}{ Date } & \multicolumn{5}{|c|}{$P$-value } \\
\hline & MSCS: & Leaf area & $\begin{array}{l}\text { Shoot } \\
\text { weight }\end{array}$ & MSCR & $\begin{array}{l}\text { Adventitious } \\
\text { root weight }\end{array}$ \\
\hline 1 & 0.11 & 0.02 & $<0.01$ & 0.37 & 0.25 \\
\hline 2 & 0.06 & 0.47 & 0.94 & 0.48 & 0.04 \\
\hline 3 & 0.74 & 0.02 & 0.03 & 0.57 & 0.00 \\
\hline 4 & 0.49 & 0.95 & 0.91 & 0.67 & 0.98 \\
\hline
\end{tabular}

† Date 1: 12 June 1995, 29 May 1996. Date 2: 26 June 1995, 12 June 1996. Date 3: 10 July 1995, 26 June 1996. Date 4: 24 July 1995, 10 July 1996. $\ddagger$ MSCR, mean stage count root; MSCS, mean stage count shoot. 
surface moisture must be available for adventitious root formation (Newman and Moser, 1988) for 3 to $5 \mathrm{~d}$ (Hyder et al., 1971; McGinnies, 1973; Wilson and Briske, 1979), frequent light rains may have favored adventitious root formation; however, when a discontinuity of soil moisture existed between the surface moisture and moisture deeper in the soil, newly initiated adventitious roots did not grow much after initiation because they came in contact with dry soil. Although HS seedlings had more adventitious roots than LS seedlings, only the earliest adventitious roots from both HS and LS seedlings penetrated sufficiently to obtain moisture deeper in the soil profile. The later-formed adventitious roots from the HS seedlings, which had a higher MSCR than LS seedlings, apparently were not able to grow because of a dry soil layer beneath the soil surface and, therefore, did not contribute to the total root weight. This agrees with the conclusion that a few long adventitious roots that reach subsurface soil moisture are needed to successfully establish a warm-season grass (Ries and Svejcar, 1991). In 1996, HS seedlings had higher adventitious root weight than LS seedlings for the second and third sampling dates but were similar at the last sampling date. Since moisture was greater and more uniformly distributed in midsummer of 1996, laterformed adventitious roots of HS seedlings continued to grow and significantly contributed to the total root weight.

Differences in emergence and biomass production of switchgrass seedlings observed by others (Aiken and Springer, 1995; Green and Bransby, 1995; Kneebone and Cremer, 1955) were apparent only between the extreme seed size classes and were observed for only a short period of time $(<30 \mathrm{~d})$. Very small seed $(<0.1 \mathrm{~g}$ $100 \mathrm{seed}^{-1}$ ) from switchgrass cultivars had germination rates of less than $10 \%$ (Aiken and Springer, 1995), which suggests that extremely light seed would not contribute significantly to stand establishment. Our seed sizes (0.13-0.21 g $100 \mathrm{seed}^{-1}$, similar to those reported above) appeared to produce only slight differences in seedling development after seedling emergence. By 8 to $10 \mathrm{wk}$ after emergence, growth and development of LS seedlings were similar to HS seedlings. Heavier seed seemed to affect the transition phase from primary root to adventitious root formation by increasing the number of adventitious roots, but the advantage to seedling establishment was minimal even when soil moisture appeared to be lacking. Once seedlings formed two or more adventitious roots, seed size no longer affected establishment and growth.

\section{Conclusion}

Heavy seed in switchgrass had greater germination, early shoot growth, and early adventitious root growth than LS seedlings. Since growth and development of HS and LS seedlings were similar by 8 to $10 \mathrm{wk}$ after emergence, we conclude that, once seedlings form two or more adventitious roots, seed size no longer affects establishment and growth. Seed size in switchgrass appears to have a minimal long-term effect on growth and develoment of seedlings.

\section{REFERENCES}

Aiken, G.E., and T.L. Springer. 1995. Seed size distribution, germination, and emergence of 6 switchgrass cultivars. J. Range Manage. $48: 455-458$.

Douglas, C.L., Jr., D.E. Wilkins, and D.B. Churchill. 1994. Tillage, seed size and seed density effects on performance of soft white winter wheat. Agron. J. 86:707-711.

Graven, L.M., and P.R. Carter. 1990. Seed size/shape and tillage system effect on corn growth and grain yield. J. Prod. Agric. $3: 445-452$.

Green, J.C., and D.I. Bransby. 1995. Effects of seed size on germination and seedling growth of 'Alamo' switchgrass. p. 183-184. In N.E. West (ed.) Proc. Int. Rangel. Congr., 5th, Salt Lake City, UT. 23-28 July 1995. Vol. 1. Soc. for Range Management, Denver, CO.

Hunter, R.B., and L.W. Kannenberg. 1972. Effects of seed size on emergence, grain yield, and plant height in corn. Can. J. Plant Sci. 52:252-256.

Hyder, D.N., A.C. Everson, and R.E. Bement. 1971. Seedling morphology and seeding failures with blue grama. J. Range Manage. 24:287-292.

Kittock, D.L., and J.K. Patterson. 1962. Seed size effects on performance of dryland grasses. Agron. J. 54:277-278.

Kneebone, W.R. 1972. Breeding for seedling vigor. p. 90-100. In V.B. Youngner and C.M. McKell (ed.) The biology and utilization of grasses. Academic Press, New York.

Kneebone, W.R., and C.L. Cremer. 1955. The relationship of seed size to seedling vigor in some native grass species. Agron. J. 47:472-477.

McGinnies, W.J. 1973. Effects of date and depth of planting on the establishment of three range grasses. Agron J. 65:120-123.

Moser, L.E., K.J. Moore, M.S. Miller, S.S. Waller, K.P. Vogel, J.R. Hendrickson, and L.A. Maddux. 1993. A quantitative system for describing the developmental morphology of grass seedling populations. p. 317-318. In J.R. Crush et al. (ed.) Proc. Int. Grassl. Congr., 17th, Palmerston North, New Zealand. 8-21 Feb. 1993. N.Z. Grassl. Assoc., Palmerston North.

Newman, P.R., and L.E. Moser. 1988. Grass seedling emergence, morphology, and establishment as affected by planting depth. Agron. J. 80:383-387.

Ries, R.E., and T.J. Svejcar. 1991. The grass seedling: When is it established? J. Range Manage. 44:574-576.

Rogler, G.A. 1954. Seed size and seedling vigor in crested wheatgrass. Agron. J. 46:216-220.

SAS Institute. 1985. SAS user's guide: Statistics. Version 6.03 ed. SAS Inst., Cary, NC.

Steel, R.G.D., and J.H. Torrie. 1980. Principles and procedures of statistics: A biometrical approach. 2nd ed. McGraw-Hill, New York

Tossell, W.E. 1960. Early seedling vigour and seed weight in relation to breeding in smooth bromegrass, Bromus inermis Leyss. Can. J. Plant Sci. 40:268-280.

Trupp, C.R., and I.T. Carlson. 1967. Progress report of improvement of stand establishment of smooth bromegrass by recurrent selection for increased seed weight. Proc. West. Grass Breed. Work Plan. Conf. 19:17-21

Wilson, A.M., and D.D. Briske. 1979. Seminal and adventitious root growth of blue grama seedlings on the central plains. J. Range Manage. 32:209-213. 